\title{
Production, Purification, and Characterization of Extracellular Alkaline Protease From Bacillus Firmus Var. Arosia NCIB 10557
}

\section{Michele Francisca Dias}

UPE: Universidade de Pernambuco

\section{Zilpa Silva das Graças da Silva}

Universidade de Pernambuco - Campus Santo Amaro

Juliana Silva de Santana

Universidade de Pernambuco - Campus Santo Amaro

Irapuan Oliveira Pinheiro

Universidade de Pernambuco - Campus Santo Amaro

ANA CÉLIA OLIVEIRA DOS SANTOS ( $\nabla$ ana.oliveira@upe.br)

Universidade de Pernambuco - Campus Santo Amaro https://orcid.org/0000-0002-9170-5684

\section{Research Article}

Keywords: Microbial protease, Bacillus firmus, Fed-batch, Partial purification

Posted Date: May 20th, 2021

DOI: https://doi.org/10.21203/rs.3.rs-520165/v1

License: (9) This work is licensed under a Creative Commons Attribution 4.0 International License. Read Full License 


\section{Abstract}

The most important alkaline proteases from the commercial standpoint are produced by bacteria of the genus Bacillus and used mainly in the formulation of detergents. The aim of the present study was to evaluate the production, partial purification, and characteristics of alkaline protease obtained by Bacillus firmus var. arosia NCIB 10557 in fed-batch fermentation with constant feeding profile and carbon source restriction. Firstly, it was carried out on batch fermentation and after $6.5 \mathrm{~h}$ of fermentation, glucose became limiting, and then the fed-batch was started with a flow rate of $0.0802 \mathrm{~mL} / \mathrm{min}$. Maximum activity $(998.1 \mathrm{U} / \mathrm{mL})$ was reached after $10.5 \mathrm{~h}$ of fed-batch, with a subsequent $60.91 \%$ drop in activity after two hours. The purification steps resulted in a 1.65 -fold increase in the value of the specific activity. The protease showed optimum activity at $37^{\circ} \mathrm{C}$ and $\mathrm{pH} 9$ and residual activity above 80 $\%$ at $\mathrm{pH} 11$ and 12 . Residual activity was greater than $70 \%$ at temperatures ranging from 30 to $70{ }^{\circ} \mathrm{C}$ and $90 \%$ of this activity was maintained for 30 minutes at $70{ }^{\circ} \mathrm{C}$ until the occurrence of complete inactivation. Enzyme activity was estimated using SDS. The organic solvents Triton X-100, Tween-20, EDTA and $\beta$-mercaptoethanol and the ions $\mathrm{Zn}^{2+}, \mathrm{Fe}^{2+}, \mathrm{Cu}^{2+}$ and $\mathrm{Ni}^{2+}$ partially inhibited the activity of the

protease. $\mathrm{Ca}^{2+}, \mathrm{Mn}^{2+}$ and $\mathrm{Mg}^{2+}$ had no stimulating action on the enzyme.

\section{Introduction}

One of the most important groups of enzymes of industrial interest are proteases and especially the alkaline produced by bacteria [1]. The representatives of the genus Bacillus are the largest producers of extracellular proteases [2,3]. Bacillus genus has been reported to present a high growth rate and is able to secrete enzymes in the extracellular medium $[4,5]$. Species of this genus produce neutral and alkaline proteolytic enzymes, widely used in industries because of their high catalytic activity and high stability at extreme temperatures, in the presence of organic solvents, detergents and oxidizing compounds [6].

The proteolytic enzymes are used in several industrial processes, such as the production of food, pharmaceuticals, as well as in fabric softening, hair removal, and detergent formulation, which is why they lead the world market for sales of enzymes $[7,8]$. Alkaline proteases, produced from submerged cultivation, have been successfully obtained using a stirred tank-type bioreactor operating in batch $[9,10]$.

The production of extracellular protease by microorganisms in bioreactor can be influenced by factors such as the composition of the culture medium, agitation, aeration, temperature, and incubation time in the fermentation system $[11,12,13]$. The synthesis of protease by Bacillus firmus no longer repressed when there limiting carbon source, nitrogen, or both, wherein in response to nutritional restriction there is an increase in enzyme synthesis [14].

Considering the scarcity of experimental data on alkaline protease from Bacillus firmus var. arosia, this article investigated the production of protease by $B$. firmus in fed-batch fermentation with a constant feeding profile and limited supply of carbon source. Partial purification and characterization of the $B$. firmus protease were also performed. 


\section{Material And Methods}

\section{Microorganism and Culture media}

Bacillus firmus var. arosia from the National Collection of Industrial Bacteria, registered under the code NCIB 10557, was used in all fermentations. The strain was isolated from a sample of seawater from the Pacific Ocean [15]. The microorganism is preserved in a lyophilized medium, based on sucrose and gelatin. Reactivation was carried out in nutrient broth and preservation by plating on nutrient agar, with $\mathrm{Na}_{2} \mathrm{CO}_{3} 1 \%$ added to both.

For all cultivations, a culture medium with the following composition was used (per liter deionized water): $15 \mathrm{~g}$ of glucose, $2 \mathrm{~g}$ urea, $5 \mathrm{~g}$ yeast extract, $10 \mathrm{~g} \mathrm{Na}_{2} \mathrm{CO}_{3}, 1 \mathrm{~g} \mathrm{KH}_{2} \mathrm{PO}_{4}, 1 \mathrm{~g} \mathrm{MgSO}_{4} .7 \mathrm{H}_{2} \mathrm{O}, 1 \mathrm{~g} \mathrm{CaCl}_{2}, 0.10 \mathrm{~g}$ $\mathrm{FeSO}_{4} .7 \mathrm{H}_{2} \mathrm{O}, 0.0088 \mathrm{~g} \mathrm{CuSO}_{4} .5 \mathrm{H}_{2} \mathrm{O}, 0.0076 \mathrm{~g} \mathrm{MnSO}_{4}$ and $0.01 \mathrm{~g} \mathrm{ZnSO}_{4} .7 \mathrm{H}_{2} \mathrm{O}[16]$.

\section{Fed-batch fermentation}

Bacillus firmus resuspended in nutrient broth was inoculated into a flask containing culture medium. The culture was maintained at $30^{\circ} \mathrm{C}$ under $180-200 \mathrm{rpm}$ agitation for 16 hours and used as inoculum for the fed-batch fermentations.

For all cultivations, the TecBio bioreactor $\left(\operatorname{TECNAL}^{\circledR}\right)$ with a working volume of $1 \mathrm{~L}$, equipped with $p H$, temperature, agitation, aeration, and peristaltic pump modules, with a thermostat bath and compressor, was used. The system was monitored using the TECBIOSoft ${ }^{\circledR}$ software. The initial working conditions were $37^{\circ} \mathrm{C}$ of temperature, $5 \mathrm{vvm}$ of aeration, rotation of $1,000 \mathrm{rpm}$, and initial $\mathrm{pH}$ of 10.5 . No pH adjustment was performed during the fermentation process.

The feeding during the fed-batch process was performed with a glucose solution $(600 \mathrm{~g} / \mathrm{L})$. The feed rate was calculated to ensure minimum concentrations of the carbon source. The Eq. 1 represents the constant feeding profile.

$$
\begin{aligned}
& \mathrm{Yx} / \mathrm{s}=\frac{\mu \cdot X \cdot V}{F \cdot S f} \\
& \mathrm{~F}=\frac{\mu \cdot X \cdot V}{\frac{Y x / s}{S f}} \quad \text { Eq. } 1
\end{aligned}
$$

where $\mu$ is the specific growth rate $\left(\mathrm{h}^{-1}\right), X$ the cell concentration at the end of the batch $(\mathrm{g} / \mathrm{L}), \mathrm{V}$ the fermenter volume $(L), Y x / s$ the substrate yield coefficient for cell production $(g / g)$, $S f$ the concentration of feed substrate $(\mathrm{g} / \mathrm{L})$ and $\mathrm{F}$ the feed flow.

The feeding of the bioreactor with a constant profile was performed by TecBio 's peristaltic pump system, using Watson-Marlow ${ }^{\circledR}$ silicone hose with an internal diameter of $0.5 \mathrm{~mm}$. The flow control was 
performed in fraction systems to achieve a flow rate of $0.0825 \mathrm{~mL} / \mathrm{min}$. The condition in which the pump worked for 3.6 seconds and stopped for 1 minute was the most appropriate, reaching a glucose flow of $0.0802 \mathrm{~mL} / \mathrm{min}$.

\section{Analytical Methods}

\section{Determination of biomass}

Biomass was monitored through a correlation between $\mathrm{OD}$ at $500 \mathrm{~nm}$ and dry cell weight (CDM) in $\mathrm{g} / \mathrm{L}$, proposed in Eq. 2. For this, the samples were vacuum filtered on a MILLIPORE ${ }^{\circledR} 0.45 \mu \mathrm{m}$ membrane and the dry weight determined after drying in an oven at $90^{\circ} \mathrm{C}$ for 24 hours.

$\operatorname{CDM}(\mathrm{g} / \mathrm{L})=0.4308 \times \mathrm{OD}_{500} \mathrm{Eq} .2$

\section{Determination of the concentration of glucose, urea, and dissolved oxygen}

The concentration of the carbon source (glucose) during fermentation was monitored using the GlucosePAP Kit (LABTEST ${ }^{\circledR}$ ) and the concentration of the nitrogen source (urea) was monitored using the Kit Urea-CE (LABTEST $\left.{ }^{\circledR}\right)$. Every 5 hours, $6 \mathrm{~mL}$ of concentrated urea solution $(320 \mathrm{~g} / \mathrm{L})$ was added to ensure non-limiting levels of this nitrogen source.

Monitoring of free oxygen percentage was carried out by use of electrodes previously calibrated through software TECBIOSoft ${ }^{\circledR}$. Control was not implemented to guarantee the maintenance of $\mathrm{O}_{2}$ dissolved in percentage value.

\section{Enzymatic assay used during fed-batch}

For carrying out the enzymatic assay during the fed-batch, $5 \mathrm{~mL}$ of $1.2 \%$ solution of casein (Fluka ${ }^{\circledR}$ ) in $\mathrm{NaHCO}_{3}$ buffer at $\mathrm{pH} 10$ was added to $1 \mathrm{~mL}$ sample of fermented broth. After 10 minutes at $30^{\circ} \mathrm{C}$, the reaction was stopped by adding $5 \mathrm{~mL}$ of protein precipitation reagent $\left(0.11 \mathrm{M} \mathrm{CCl}_{3} \mathrm{COOH}, 0.22 \mathrm{M}\right.$ $\mathrm{CH}_{3} \mathrm{COONa}$, and $0.33 \mathrm{M} \mathrm{CH}_{3} \mathrm{COOH}$ ). The resulting suspension was filtered on Whatman $\mathrm{GF} / \mathrm{A}^{\circledR}$ filter paper. The absorbance of the filtrate was read at $275 \mathrm{~nm}$, using a blank prepared in a similar way, but to this was firstly added precipitation reagent, and then casein. The tests were performed in duplicates. A standard tyrosine curve was previously constructed using a solution of L-tyrosine MERCK ${ }^{\circledR}(200 \mu \mathrm{g} / \mathrm{mL})$ diluted in $0.2 \mathrm{M} \mathrm{HCl}$ obtaining different concentrations. Activity was expressed in $\mathrm{U} / \mathrm{mL}$, corresponding to $\mu \mathrm{g}$ (tyrosine)/min.mL [17].

\section{Enzymatic assay used in the purification steps and characterization of $B$. firmus protease}

The enzymatic assay used to quantify the protease activity during the steps involving partial purification and characterization of the protease produced by $B$. firmus was based on Bezerra et al. [18], with modifications. For this, the reaction occurred in microcentrifuge tubes, which were added $50 \mu \mathrm{L}$ of $1 \%$ azocasein $(0.1 \mathrm{M}$ Tris- $\mathrm{HCl}, \mathrm{pH} 9)$ with $30 \mu \mathrm{L}$ fermented broth and the tubes incubated for 10 minutes at 
$37^{\circ} \mathrm{C}$. Thereafter, $240 \mu \mathrm{L}$ of $10 \%$ trichloroacetic acid (TCA) was added to stop the reaction. After 15 minutes, centrifugation was performed at $8,000 \mathrm{rpm}$ for 5 minutes. The supernatant $(70 \mu \mathrm{L})$ was added to $130 \mu \mathrm{L}$ of $1 \mathrm{M} \mathrm{NaOH}$ in a microtiter plate, using the reader (Bio-rad ${ }^{\circledR}$ ) at $450 \mathrm{~nm}$, against a similarly prepared blank, except for the addition of $0.1 \mathrm{M} \mathrm{Tris-HCl}$ at $\mathrm{pH} 9$ to replace the sample. The unit of enzyme activity was defined as the amount of enzyme capable of hydrolyzing hemoglobin or azocasein and producing 0.001 absorbance per minute [19]. The tests were performed in duplicates.

\section{Partial purification of alkaline protease produced by $B$. firmus}

For the extraction of protease from the fermented broth supernatant, precipitation with acetone at low temperatures $\left(-18^{\circ} \mathrm{C}\right)$ was used until reaching a concentration of $75 \%$ acetone $\left(\right.$ MERCK $\left.^{\circledR}\right)(\mathrm{v} / \mathrm{v})$. For this, $150 \mathrm{ml}$ of acetone was added to $50 \mathrm{ml}$ of the fermented broth. This mixture was kept refrigerated for 24 hours and centrifuged at $6,000 \mathrm{rpm}$ for 30 minutes at $-4^{\circ} \mathrm{C}$. The pellet formed was resuspended in $0.1 \mathrm{M}$ Tris-HCL buffer at $\mathrm{pH}$ 9.0. Protein concentration was determined using a BSA curve and enzyme activity was performed according to section Enzymatic assay used in the purification steps and characterization of $B$. firmus protease [20].

The resuspension resulting from the previous step was applied to a gel chromatography column on gel filtration (Sephadex G-75) in a volume not exceeding $10 \%$ of the resin volume. The column $(44 \times 1.6 \mathrm{~cm})$, with a flow of $0.38 \mathrm{~mL} / \mathrm{min}$, was eluted in Tris- $\mathrm{HCl}(0.1 \mathrm{M}$ and pH 9), with 157 fractions of $1 \mathrm{~mL}$ being collected. For each fraction, an enzymatic assay was performed according to section 2.3.4, estimation of protein concentration through absorbance in a Halo DB-20 spectrophotometer (Dynamica ${ }^{\circledR}$ ) at $280 \mathrm{~nm}$, and determination of protein concentration according to Lowry et al. [20].

\section{Characterization of alkaline protease produced by B.firmus in fed-batch}

\section{Determination of optimum temperature for enzyme activity}

To determine the optimal temperature, the enzymatic assay methodology proposed in the section Enzymatic assay used in the purification steps and characterization of B. firmus protease was used, varying the incubation temperatures. The tested temperatures were 30,37 , and $40^{\circ} \mathrm{C}$. The relative activities were determined considering $100 \%$ the temperature where there was the highest enzyme activity. The tests were performed in duplicates.

\section{Determination of the optimum pH for enzyme activity}

To determine the optimum $\mathrm{pH}$, the enzymatic assay methodology proposed in the section Enzymatic assay used in the purification steps and characterization of $B$. firmus protease was used, replacing only the azocasein dissolution buffer. The buffers were $0.1 \mathrm{M}$ acetate/acetic acid $(\mathrm{pH} 5), 0.1 \mathrm{M}$ Tris- $\mathrm{HCl}(\mathrm{pH} 7$ and 9), $0.1 \mathrm{M}$ Borax- $\mathrm{NaOH}$ ( $\mathrm{pH} 11$ and 12) and $0.1 \mathrm{M} \mathrm{KCl}-\mathrm{NaOH}(\mathrm{pH} 13)$. The relative activities were determined considering $100 \%$ the $\mathrm{pH}$ at which the highest enzyme activity was observed.

\section{Determination of the effect of temperature on enzyme activity}


The effect of temperature on the activity of the enzyme was evaluated by incubating the enzyme for 5 , 10,20 , and 30 minutes at temperatures of 30 to $100^{\circ} \mathrm{C}$. After the pre-incubation period, the enzymatic assay was performed according to section Enzymatic assay used in the purification steps and characterization of $B$. firmus protease. The residual activity of the enzyme was expressed as a percentage.

\section{Determination of the thermal stability of the enzyme}

The thermal stability of the enzyme was evaluated by incubating the enzyme for $10,20,30,40,50$, and 60 minutes at $70{ }^{\circ} \mathrm{C}$. After the pre-incubation period, an enzymatic assay was performed according to section Enzymatic assay used in the purification steps and characterization of B. firmus protease. The residual activity of the enzyme was expressed as a percentage.

\section{Determination of the effect of detergents on enzyme activity}

The effect of SDS, Triton X-100, and Tween-20 detergents on enzyme activity was assessed by preincubating the enzyme with the detergent under analysis for 10 minutes at $37^{\circ} \mathrm{C}$. The detergents were tested in concentrations of $0.5 \%, 1 \%$, and $5 \%$. After this step, the enzyme assay was carried out according to section Enzymatic assay used in the purification steps and characterization of B. firmus protease.

\section{Determination of the effect of organic solvents on enzyme activity}

The effect of butanol, methanol, isopropanol, and DMSO organic acids on enzyme activity was determined by pre-incubating the enzyme with the solvent under analysis for 10 minutes at $37^{\circ} \mathrm{C}$. The solvents were tested in concentrations of $0.5 \%, 1 \%$, and $5 \%$. After this step, the enzyme assay was carried out according to section Enzymatic assay used in the purification steps and characterization of $B$. firmus protease.

\section{Determination of the effect of inhibitors on enzyme activity}

The effect of EDTA and $\beta$-mercaptoethanol inhibitors on enzyme activity was assessed by pre-incubating the enzyme with the inhibitor under analysis for 10 minutes at $37^{\circ} \mathrm{C}$. The inhibitors were tested in concentrations of $0.5 \%, 1 \%$, and $5 \%$. After this step, the enzyme assay was carried out according to section Enzymatic assay used in the purification steps and characterization of $B$. firmus protease.

\section{Determination of the effect of salts on enzyme activity}

The effect of $\mathrm{CaCl}_{2}, \mathrm{CuSO}_{4}, \mathrm{MnSO}_{4}, \mathrm{NiSO}_{4}, \mathrm{CuCl}_{2}, \mathrm{MgSO}_{4}, \mathrm{ZnSO}_{4}$, and $\mathrm{FeSO}_{4}$ ions on the enzyme was evaluated by pre-incubating the enzyme with the analyzed salt for 10 minutes at $37^{\circ} \mathrm{C}$. The salts were tested at concentrations of 0.01 and $0.005 \mathrm{M}$. After this step, the enzyme assay was carried out according to section Enzymatic assay used in the purification steps and characterization of $B$. firmus protease. 


\section{Results And Discussion}

\section{General parameters of fed-batch fermentations for protease production by Bacillus firmus}

The microbial growth of Bacillus firmus var. arosia was started immediately after the addition of the inoculum to the production medium (Fig. 1a). In the literature, there are reports that this also occurs with other strains of $B$. firmus [21, 22]. In this study, after 19 hours of fed-batch, the maximum biomass concentration achieved was $24.81 \mathrm{~g} / \mathrm{L}$, a result similar $(24.82 \mathrm{~g} / \mathrm{L})$ to that obtained by Costa [16] using the same bacillus and medium of production, but in longer cultivation time. In contrast, Pleurotus ostreatus, which also produces protease, only reached the maximum biomass value after 9 days of cultivation, which demonstrates that the microbial growth time is variable and dependent on metabolic and extrinsic factors such as cultivation time, medium and temperature [23]. These variables significantly affect the evolution of biomass in submerged cultivations [24]. The temperature affects the rate of enzyme reactions, determining the metabolic energy and biomass synthesis throughout the fermentation time $[25,26]$.

Throughout the fermentation process, the urea concentration was maintained at non-limiting levels (2 $\mathrm{g} / \mathrm{L}$ ), ensuring that only the carbon source was limiting during protease synthesis. The initial $\mathrm{pH}$ value was 10.4 and after inoculation, it suffered a slight decline as the substrate was consumed and remained at pH 9.0 until the end of the experiment (Fig. 1a). This is in accordance with the metabolic profile of $B$. firmus, which is a microorganism capable of regulating the $\mathrm{pH}$ of the medium to ideal values for its growth $[27,28]$. This is crucial since the $\mathrm{pH}$ of the culture strongly influences several enzymatic processes and component transport across the cell membrane, which in turn can favor the growth of the microorganism and product synthesis, with a significant effect on the growth of strains of Bacillus sp. $[29,30]$.

Agitation and aeration in fermentation systems are also crucial factors in microbial cultures, so the best combination of these factors can have a positive impact on the production of alkaline protease in submerged cultivations in stirred tank bioreactor [10,31, 32]. For this reason, in fermentations, the maximum oxygen and rotation required were provided, so that oxygen would not become a limiting factor.

Before the start of fermentation, the free oxygen percentage in the medium was $104 \%$. With the start of fermentation, the percentage of free oxygen was reduced due to the increase in the consumption rate of $B$. firmus. The beginning of the fed-batch was marked by a sudden increase in the percentage of available oxygen in the medium, the same registered by Marques [28] in cultivations with this microorganism but in the medium based on molasses. During the fed-batch stage, oxygen remained at $0 \%$ (Fig. 1b). The increase in viscosity of the medium throughout the fermentation time inevitably impaired the oxygen transfer rate causing stress conditions, since $B$. firmus is aerobic. This could have been avoided if the compressor module of the bioreactor could more efficiently supply the need for oxygen consumption required by growing cells. 
Through the regulation of the feed flow of the fermentative process carried out by the TECBIOSoft ${ }^{\circledR}$ software, it was possible to control the concentration of limiting substrate in the cultivation, allowing the adaptation of the feed to the restriction conditions that stimulated the enzyme production [33]. In studies that evaluated the response of $B$. firmus to nutritional limitations, in a chemically defined medium, containing glucose and urea, it was demonstrated that protease synthesis is unrepressed when microbial growth is limited by the availability of nitrogen, carbon, or both [34,35]. In this study, the protease production became significant after 6.5 hours of microbial growth, when glucose became limiting $(0.014$ $\mathrm{g} / \mathrm{L}$ ), marking the beginning of the fed-batch where a significant increase in enzyme activity values can be noted. The maximum enzymatic activity $(998.41 \mathrm{U} / \mathrm{mL})$ was reached after 10.5 hours of fed-batch (Fig. 2).

The choice of carbon source is very important due to the fact that the synthesis of several biomolecules is subject to catabolic repression. Several sources of carbon, such as glucose for example, although, in general, excellent for the growth of microorganisms, have been reported as a repressor for the synthesis of several biomolecules, in particular for the production of enzymes [36-39]. In order to prevent $B$. firmus had catabolic repression, it was decided to keep glucose concentrations at minimum levels, ensuring protease synthesis.

The reduction in the availability of carbon sources can induce the synthesis of extracellular proteases in order to release amino acids from the culture medium for the synthesis of proteins and for the production of energy by protein metabolism. The production of proteases by Aspergillus carbonarius in submerged cultivations was also strongly influenced by the concentration of carbon and nitrogen in the production medium, however in this case the synthesis of protease is stimulated in the presence of glucose, indicating that it does not undergo catabolic repression, contrary to $B$. firmus [40]. Studies involving Bacillus sp. P45 demonstrated that supplementation of the medium with carbohydrates resulted in a reduction in the production of proteases, probably caused by catabolic repression [41].

In this study, in approximately 2 hours, $60.91 \%$ of the maximum value of the achieved enzymatic activity was lost, a situation similar to what occurred with proteases from Bacillus sp. thermophilic [42]. The rate of protease production has decreased dramatically due to the increased severity of nutritional and oxygen conditions.

\subsection{Partial purification of the alkaline protease of $B$. firmus obtained in fed-batch}

The resulting sample from step precipitation with acetone $(75 \% \mathrm{v} / \mathrm{v})$ was applied in a liquid gel-filtration column, resulting in increased protein concentration $(0.95 \mathrm{mg} / \mathrm{mL})$ and enzyme activity values $(1078.00$ $\mathrm{U} / \mathrm{mL}$ ) in fraction 67 (Fig. 3). The purification steps resulted in an increase of 1.65 in the values of specific activity (Table 1). Precipitation and chromatography (Sepharose-Q) are techniques commonly applied in the purification of enzymes, and when they were used in Bacillus cereus proteases, an increase of 1.8 in activity values was obtained [43].

\subsection{Characterization of the alkaline protease of $B$. firmus obtained in fed-batch}


The enzymatic assay of the protease of $B$. firmus was evaluated at different temperatures (Fig. 4a). The optimum temperature for carrying out the enzymatic assay was $37^{\circ} \mathrm{C}$, a similar result was found for proteases produced by various strains of Bacillus sp. $[44,45]$. In this study, it was found that between 30 and $40^{\circ} \mathrm{C}$ was preserved from 77.5 to $80 \%$ of the enzyme activity, a characteristic thermostable useful for the detergent industry.

The effect of $\mathrm{pH}$ on $B$. firmus protease was also evaluated (Fig. 4b), verifying that maximum enzymatic activity was observed at $\mathrm{pH}$ 9.0. A similar result on the influence of $\mathrm{pH}$ on enzyme activity was reported in proteases from Streptomyces sp. [46], Bacillus subtilis sp. [47], Bacillus sp. P7 [48], Bacillus filamentosus, Lysinibacillus cresolivorans [49] and Bacillus sphaericus DS11 [50]. For B. firmus, it was observed that relative enzymatic activity greater than $80 \%$ was observed at $\mathrm{pH} 11$ and 12 , indicating a predominantly alkaline character (Fig. 4b). Alkaline microbial proteases that exhibit thermostability are versatile and present numerous industrial applications.

The influence of temperature on the activity of the protease from B. firmus (Fig. 5a) was investigated and it was noted that the protease showed residual activity above $70 \%$ at temperatures of $30-70^{\circ} \mathrm{C}$, regardless of the incubation time. Bacillus subtilis $\mathrm{SH} 1$ also showed a broad activity spectrum in the range of 40$60^{\circ} \mathrm{C}$. These results demonstrate the industrial potential of microbial proteases [51]. However, at temperatures above $80^{\circ} \mathrm{C}$ the protease of $B$. firmus underwent a rapid inactivation process.

When the alkaline protease of $B$. firmus was incubated at $70^{\circ} \mathrm{C}$ for 30 minutes, a residual activity greater than $90 \%$ was observed and subsequently, the protease underwent a rapid decline in activity values until it was completely inactivated after 1 hour (Fig. 5b). Similarly, the protease of $B$. licheniformis RBS5 showed stability at $60^{\circ} \mathrm{C}$ for a maximum of 30 minutes [52].

The Triton X-100, a non-ionic detergent, showed a negative effect on the activity of the protease of $B$. firmus, which was also evidenced in proteases from Bacillus sp. P45 [53], in both cases, the Triton X-100 acted by destabilizing the enzymatic structure. In contrast, the SDS that is cited in the literature as an enzyme inhibitor [54] stimulated protease activity (Table 2). Proteases from Bacillus safensis CK [55] and Bacillus pumilus D3 [56] in the presence of SDS also showed an increase in the values of enzyme activity, demonstrating that the inhibitor did not have a negative effect on these enzymes. The Tween-20 (5\%) caused a $42.86 \%$ residual loss in $B$. firmus protease activity.

In this study, it was found that as the concentration of organic solvents increased, there was a decrease in residual enzyme activity. Butanol, methanol, isopropanol, and DMSO in the highest concentration (5\%) maintained $54.61 \%, 67.28 \%, 62.44 \%$, and $56.45 \%$, respectively, of the enzyme activity values (Table 2 ). The microorganism Bacillus cereus S8, which produces proteases, in the presence of methanol maintained less than $40 \%$ of the enzymatic activity, while butanol and isopropanol caused losses above $40 \%$ and $60 \%$, respectively, in the enzyme activity values. DMSO did not affect protease activity [57]. The protease from Bacillus sp. ZJ1502 lost more than 25\% of enzyme activity in the presence of DMSO [58]. The stability of proteases can allow them to be used in organic solvents by changing the balance of reversible reactions between hydrolysis and peptide synthesis [59]. 
The enzymatic activity of the protease of $B$. firmus was inhibited in the presence of the reducing agent $\beta$ mercaptoethanol (Table 2), indicating that the group (-SH) is not essential for catalytic activity. This reducing agent also slightly inhibited proteases from Bacillus sps [60]. EDTA caused inhibition of the protease of $B$. firmus (Table 2), as was also reported their inhibitory effect on the alkaline protease of $B$. licheniformis A10 [61] and Bacillus sp. ZJ1502 [58].

The effect of ions on enzyme activity is variable and depends on the enzyme evaluated and on the structure and concentration of the ion. The $\mathrm{Zn}^{2+}, \mathrm{Ni}^{2+}, \mathrm{Cu}^{2+}$, and $\mathrm{Fe}^{2+}$ ions caused inhibition of $65.22 \%$, $58.78 \%, 49.20 \%$, and $50.80 \%$, respectively, the enzyme activity values protease of $B$. firmus (Table 2 ). The inhibitory effect of $\mathrm{Zn}^{2+}$ in protease of Bacillus cereus S8 [57] and $\mathrm{Ni}^{2+}$ or $\mathrm{Fe}^{2+}$ in protease of Bacillus licheniformis A10 [61] has also been reported in the literature. The $\mathrm{Ca}^{2+}, \mathrm{Mn}^{2+}$, and $\mathrm{Mg}^{2+}$ ions $(0.005 \mathrm{M})$ caused less damage to the protease enzyme, with loss of only $11.54 \%, 27.88 \%$, and $28.33 \%$, respectively, in the enzyme activity values (Table 2). There are reports in the literature that the metal ions $\mathrm{Ca}^{2+}, \mathrm{Mg}^{2+}$, and $\mathrm{Mn}^{2+}$ can stimulate the enzymatic activity, stabilizing its protein structure [62]. However, it has also been reported that these ions acted as inhibitors of the protease of Bacillus cereus MTCC 6840 [63].

\section{Conclusions}

The process of fed-batch fermentation with constant feeding profile and restriction of the carbon source proved to be efficient for the production of protease by $B$. firmus var. arosia in submerged cultivations using a synthetic medium. The need for a more efficient air supply system was evident since the increase in the viscosity of the medium can impair the oxygen supply to the growing cells. The partial purification and characterization revealed that the protease from $B$. firmus exhibits thermoresistance, a predominantly alkaline nature and compatibility with solvents and salts, which are potentially advantageous characteristics from the industrial standpoint.

\section{Declarations}

\section{Acknowledgments}

The authors acknowledge the researcher Dra. Ana Maria Souto Maior, from the Federal University of Pernambuco, for supplying microorganism, and FACEPE (Foundation of Support to Science and Technology of the State of Pernambuco) for student scholarships.

\section{Funding}

This work was carried out with the support of the Coordination for the Improvement of Higher Education Personnel - Brazil (CAPES) - Financing Code 001; also had support from the Foundation for the Support of Science and Technology of Pernambuco - FACEPE, through the granting of the scholarship for author MFD. 
The authors declare no competing interests.

\section{Availability of data and material}

Not applicable.

\section{Code availability}

Not applicable.

\section{References}

1. Sharma, K. M., Kumar, R., Panwar, S., \& Kumar, A. (2017). Microbial alkaline proteases: optimization of production parameters and their properties. Journal of Genetic Engineering and Biotechnology, 15(1), 115-126.

2. Alnahdi, H. S. (2012). Isolation and screening of extracellular proteases produced by new isolated Bacillus sp. Journal of Applied Pharmaceutical Science, 2(9), 71-74.

3. Butt, K. Y., Altaf, A., Malana, M. A., Ghori, M. I., \& Jamil, A. (2018). Optimal production of proteases from Bacillus subtilis using submerged fermentation. Pakistan Journal of Life and Social Sciences, 16(1), 15-19.

4. Devaraj, K., Aathika, S., Periyasamy, K., Periyaraman, P., Palaniyandi, S., \& Subramanian, S. (2019). Production of thermostable multiple enzymes from Bacillus amyloliquefaciens KUB29. Natural Product Research, 33(11), 1674-1677.

5. Schallmey, M., Singh, A., \& Ward, O. P. (2004). Developments in the use of Bacillus species for industrial production. Canadian Journal of Microbiology, 50(1), 1-17.

6. Contesini, F. J., Melo, R., \& Sato, H. H. (2018). An overview of Bacillus proteases: from production to application. Critical Reviews in Biotechnology, 38(3), 321-334.

7. Naveed, M., Nadeem, F., Mehmood, T., Bilal, M., Anwar, Z., \& Amjad, F. (2021). Protease - a versatile and ecofriendly biocatalyst with multi-industrial applications: an updated review. Catalysis Letters, 151(2), 307-323.

8. Thakur, N., Goyal, M., Sharma, S., \& Kumar, D. (2018). Proteases: industrial applications and approaches used in strain improvement. Biological Forum - An International Journal, 10(1), 158167.

9. Hakim, A., Bhuiyan, F. R., Iqbal, A., Emon, T. H., Ahmed, J., \& Azad, A. K. (2018). Production and partial characterization of dehairing alkaline protease from Bacillus subtilis AKAL7 and Exiguobacterium indicum AKAL11 by using organic municipal solid wastes. Heliyon, 4(6), 646.

10. Potumarthi, R., Nagavalli, K., \& Jetty, A. (2012). Kinetic analysis of alkaline protease production at different substrate concentrations by Bacillus licheniformis - NCIM 2042 in stirred tank reactor. Biosciences Biotechnology Research Asia, 9(1), 331-337. 
11. Aguilar, J. G., Castro, R. J., \& Sato, H. H. (2019). Alkaline protease production by Bacillus licheniformis LBA 46 in a bench reactor: effect of temperature and agitation. Brazilian Journal of Chemical Engineering, 36(2), 615-625.

12. Arumugam, N., Dhandapani, B., \& Mahadevan, S. (2020). Optimized production of extracellular alkaline protease from Aspergillus tamarii with natural by-products in a batch stirred tank bioreactor. Preparative Biochemistry \& Biotechnology, 50(10), 992-999.

13. Hammami, A., Bayoudh, A., Abdelhedi, O., \& Nasri, M. (2018). Low-cost culture medium for the production of proteases by Bacillus mojavensis SA and their potential use for the preparation of antioxidant protein hydrolysate from meat sausage by-products. Annals of Microbiology, 68(8), 473484.

14. Moon, S. H., \& Parulekar, S. J. (1991). A parametric study of protease production in batch and fedbatch cultures of Bacillus firmus. Biotechnology and Bioengineering, 37(5), 467-483.

15. Villadsen, K. J. S., \& Vestberg, K. P. (1976). U.S. Patent No. 3,960,665. Washington, DC: U.S. Patent and Trademark Office.

16. Costa, C. S. (2005). Produção de protease por Bacillus firmus via batelada alimentada utilizando-se perfis constante e exponencial de alimentação [Thesis]. Recife: Universidade Federal de Pernambuco.

17. Hagihara, B., Matsubara, H., Nakai, M., \& Okunuki, K. (1958). Crystalline bacterial proteinase I. preparation of crystalline proteinase of Bacillus subtilis. The Journal of Biochemistry, 45(3), 185194.

18. Bezerra, R. S., Lins, E. J., Alencar, R. B., Paiva, P. M., Chaves, M. E., Coelho, L. C., \& Junior, L. B. (2005). Alkaline proteinase from intestine of Nile tilapia (Oreochromis niloticus). Process Biochemistry, 40(5), 1829-1834.

19. Warburg, O., \& Christian, W. (1941). Isolierung und kristallisation des gärungsferments enolase. Die Naturwissenschaften, 29(39), 589-590.

20. Lowry, O. H., Rosebrough, N. J., Farr, A. L., \& Randall, R. J. (1951). Protein measurement with the Folin phenol reagent. Journal of Biological Chemistry, 193, 265-275.

21. Annamalai, N., Rajeswari, M. V., Sahu, S. K., \& Balasubramanian, T. (2014). Purification and characterization of solvent stable, alkaline protease from Bacillus firmus CAS 7 by microbial conversion of marine wastes and molecular mechanism underlying solvent stability. Process Biochemistry, 49(6), 1012-1019.

22. Rao, K., \& Narasu, M. L. (2007). Alkaline protease from Bacillus firmus 7728. African Journal of Biotechonology, 6(21), 2493-2496.

23. Campos, C., Dias, D. C., Valle, J. S., Colauto, N. B., \& Linde, G. A. (2010). Produção de biomassa, protease e exopolissacarídeos por Pleurotus ostreatus em cultivo líquido. Arquivos de Ciência Veterinária e Zoologia, 13(1), 19-24.

24. Pinotti, L. M., Paulino, L. B., Agnezi, J. C., Santos, P. A., Silva, H. N., Zavarise, J. P., Salomão, G. S., \& Tardioli, P. W. (2020). Evaluation of different fungi and bacteria strains for production of cellulases 
by submerged fermentation using sugarcane bagasse as carbon source: effect of substrate concentration and cultivation temperature. African Journal of Biotechnology, 19(9), 625-635.

25. Arcus, V. L., Prentice, E. J., Hobbs, J. K., Mulholland, A. J., Van der Kamp, M. W., Pudney, C. R., Parker, E. J., \& Schipper, L. A. (2016). On the temperature dependence of enzyme-catalyzed rates. Biochemistry, 55(12), 1681-1688.

26. Wang, Y., Zhang, L., Xu, T., \& Ding, K. (2017). Influence of initial anolyte pH and temperature on hydrogen production through simultaneous saccharification and fermentation of lignocellulose in microbial electrolysis cell. International Journal of Hydrogen Energy, 42(36), 22663-22670.

27. Souto-Maior, A. M., Marques, O. M., \& Pontual, R. S. (1997). Effect of the initial pH on the growth of a proteinase-producing alkalophilic Bacillus species. Arquivos de Biologia e Tecnologia, 40(3), 616623.

28. Marques, O. M. (1998). Produção de proteinase por Bacillus firmus em meio de melaço [Thesis]. Recife: Universidade Federal de Pernambuco.

29. Gorlach-Lira, K., Pedroza, M. L. V., Burdziej-Pokojska, A., Rozycki, H., \& Dahm, H. (2010). Response surface analysis on the effect of temperature and $\mathrm{pH}$ on growth and proteolytic activity of thermophilic Bacillus sp. Brazilian Archives of Biology and Technology, 53(5), 1067-1072.

30. Zhu, B., \& Xu, Y. (2010). Production of tetramethylpyrazine by batch culture of Bacillus subtilis with optimal pH control strategy. Journal of Industrial Microbiology and Biotechnology, 37(8), 815-821.

31. Nadeem, M., Qazi, J. I., \& Baig, S. (2009). Effect of aeration and agitation rates on alkaline protease production by Bacillus licheniformis UV-9 mutant. Türk Biyokimya Dergisi, 34(2), 89-96.

32. Ravishankar, K., Kumar, M. A., \& Saravanan, K. (2012). Isolation of alkaline protease from Bacillus subtilis AKRS3. African Journal of Biotechnology, 11(69), 13415-13427.

33. Souto-Maior, A. M., \& Simões, D. A. (2000). Uso e produção de proteases microbianas alcalinas. Revista Brasileira de Engenharia Química, 19(1), 10-14.

34. Souto-Maior, A. M. (1991). Proteinase production from an alkalophilic Bacillus species [Thesis]. Manchester: University of Manchester.

35. Souto-Maior, A. M. (1994). Proteinase production from an alkalophilic. Bacillus species. Arquivos de Biologia e Tecnologia, 37(2), 247-255.

36. Bhunia, B., Dutta, D., \& Chaudhuri, S. (2010). Selection of suitable carbon, nitrogen and sulphate source for the production of alkaline protease by Bacillus licheniformis NCIM-2042. Notulae Scientia Biologicae, 2(2), 56-59.

37. Çalik, P., \& Özdamar, T. H. (2001). Carbon sources affect metabolic capacities of Bacillus species for the production of industrial enzymes: theoretical analyses for serine and neutral proteases and aamylase. Biochemical Engineering Journal, 8(1), 61-81.

38. Lane, S., Xu, H., Oh, E. J., Kim, H., Lesmana, A., Jeong, D., Zhang, G., Tsai, C., Jin, Y., \& Kim, S. R. (2018). Glucose repression can be alleviated by reducing glucose phosphorylation rate in Saccharomyces cerevisiae. Scientific reports, 8(1), 1-12. 
39. Vijayalakshmi, S., Ranjitha, J., \& Rajeswari, V. D. (2013). Enzyme production ability by Bacillus subtilis and Bacillus licheniformis - a comparative study. Asian Journal of Pharmaceutical and Clinical Research, 6(4), 235-238.

40. Ire, F. S., Okolo, B. N., Moneke, A. N., \& Odibo, F. J. (2011). Influence of cultivation conditions on the production of a protease from Aspergillus carbonarius using submerged fermentation. African Journal of Food Science, 5(6), 353-365.

41. Daroit, D. J. (2011). Potencial queranolítico e caracterização de uma queratinase extracelular de Bacillus sp. P45 [Thesis]. Porto Alegre: Universidade Federal do Rio Grande do Sul.

42. Nascimento, W. C., Silva, C. R., Carvalho, R. V., \& Martins, M. L. (2007). Optimization of a culture medium for protease production by Bacillus sp. thermophilic. Food Science and Technology, 27(2), 417-421.

43. Doddapaneni, K., Tatineni, R., Vellanki, R. N., Rachcha, S., Anabrolu, N., Narakuti, V., \& Mangamoori, L. N. (2009). Purification and characterization of a solvent and detergent-stable novel protease from Bacillus cereus. Microbiological Research, 164(4), 383-390.

44. Briki, S., Hamdi, O., \& Landoulsi, A. (2016). Enzymatic dehairing of goat skins using alkaline protease from Bacillus sp. SB12. Protein Expression and Purification, 121, 9-16.

45. Padmapriya, M., \& Williams, B. C. (2012). Purification and characterization of neutral protease enzyme from Bacillus subtilis. Journal of Microbiology and Biotechnology Research, 2(4), 612-618.

46. Xie, F., Chao, Y., Yang, X., Yang, J., Xue, Z., Luo, Y., \& Qian, S. (2010). Purification and characterization of four keratinases produced by Streptomyces sp. strain 16 in native human foot skin medium. Bioresource Technology, 101(1), 344-350.

47. Hussain, F., Kamal, S., Rehman, S., Azeem, M., Bibi, I., Ahmed, T., \& Iqbal, H. M. (2017). Alkaline protease production using response surface methodology, characterization and industrial exploitation of alkaline protease of Bacillus subtilis sp. Catalysis Letters, 147(5), 1204-1213.

48. Corrêa, A. P. F., Daroit, D. J., \& Brandelli, A. (2010). Characterization of a keratinase produced by Bacillus sp. P7 isolated from an Amazonian environment. International Biodeterioration \& Biodegradation, 64(1), 1-6.

49. Ullah, I., Ali, N., Ullah, W., Qasim, M., Nughman, M., Ullah, N., \& Rashid, M. (2021). Purification, characterization and application of thermoalkaliphilic proteases from Bacillus filamentosus, Lysinibacillus cresolivorans, and Bacillus subtilis. Research Square, 1-14.

50. Wu, X., Ahmed, S., Cui, X., Hang, J., Wang, S., Liu, S., \& Fang, Y. (2021). Expression and characterization of a novel organic solvent tolerant protease from Bacillus sphaericus DS11. Preparative Biochemistry \& Biotechnology, 51(1), 28-34.

51. Ningthoujam, D. S., \& Kshetri, P. (2010). A thermostable alkaline protease from a moderately haloalkali thermotolerant Bacillus subtilis strain SH1. Australian Journal of Basic and Applied Sciences, 4(10), 5126-5134.

52. Salem, R. B., Abbassi, M. S., Cayol, J. L., Bourouis, A., Mahrouki, S., Fardeau, M. L., \& Belhadj, 0. (2016). Thermophilic Bacillus licheniformis RBS 5 isolated from hot Tunisian spring co-producing 
alkaline and thermostable a-amylase and protease enzymes. Journal of Microbiology, Biotechnology and Food Sciences, 5(6), 557-562.

53. Daroit, D. J., Corrêa, A. P. F., \& Brandelli, A. (2011). Production of keratinolytic proteases through bioconversion of feather meal by the Amazonian bacterium Bacillus sp. P45. International Biodeterioration \& Biodegradation, 65(1), 45-51.

54. Kjølbye, L. R., Laustsen, A., Vestergaard, M., Periole, X., De Maria, L., Svendsen, A., Coletta, A., \& Schiøtt, B. (2019). Molecular modeling investigation of the interaction between Humicola insolens cutinase and SDS surfactant suggests a mechanism for enzyme inactivation. Journal of Chemical Information and Modeling, 59(5), 1977-1987.

55. Jalkute, C. B., Waghmare, S. R., Nadaf, N. H., Dhanavade, M. J., Jadhav, D. B., Pendhari, S. I., Patil, R. S., \& Sonawane, K. D. (2017). Purification and characterization of SDS stable protease from Bacillus safensis strain CK. Biocatalysis and Agricultural Biotechnology, 10, 91-95.

56. Özçelik, B., Aytar, P., Gedikli, S., Yardimci, E., Çalişkan, F., \& Çabuk, A. (2014). Production of an alkaline protease using Bacillus pumilus D3 without inactivation by SDS, its characterization and purification. Journal of Enzyme Inhibition and Medicinal Chemistry, 29(3), 388-396.

57. Lakshmi, B. K. M., Kumar, D. M., \& Hemalatha, K. P. J. (2018). Purification and characterization of alkaline protease with novel properties from Bacillus cereus strain S8. Journal of Genetic Engineering and Biotechnology, 16(2), 295-304.

58. Yu, P., Huang, X., Ren, Q., \& Wang, X. (2019). Purification and characterization of a $\mathrm{H}_{2} \mathrm{O}_{2}$-tolerant alkaline protease from Bacillus sp. ZJ1502, a newly isolated strain from fermented bean curd. Food Chemistry, 274, 510-517.

59. Karadzic, I., Masui, A., \& Fujiwara, N. (2004). Purification and characterization of a protease from Pseudomonas aeruginosa grown in cutting oil. Journal of Bioscience and Bioengineering, 98(3), 145-152.

60. Thomas, N. N., Archana, V., Shibina, S., \& Edwin, B. T. (2021). Isolation and characterization of a protease from Bacillus sps. Materials Today: Proceedings, 41, 685-691.

61. Yilmaz, B., Baltaci, M. O., Sisecioglu, M., \& Adiguzel, A. (2016). Thermotolerant alkaline protease enzyme from Bacillus licheniformis A10: purification, characterization, effects of surfactants and organic solvents. Journal of Enzyme Inhibition and Medicinal Chemistry, 31(6), 1241-1247.

62. Harer, S. L., Bhatia, M. S., \& Bhatia, N. M. (2018). Isolation, purification and partial characterization of thermostable serine alkaline protease from a newly isolated Bacillus thuringinsis-SH-II-1A. African Journal of Biotechnology, 17(7), 178-188.

63. Joshi, G. K., Kumar, S., \& Sharma, V. (2007). Production of moderately halotolerant, SDS stable alkaline protease from Bacillus cereus MTCC 6840 isolated from lake Nainital, Uttaranchal state, India. Brazilian Journal of Microbiology, 38(4), 773-779.

\section{Tables}


Table 1 Partial purification of extracellular alkaline protease from B. firmus

\begin{tabular}{|lllll|}
\hline $\begin{array}{l}\text { Purification } \\
\text { step }\end{array}$ & $\begin{array}{l}\text { Enzyme activity } \\
(\mathbf{U} / \mathrm{mL})\end{array}$ & $\begin{array}{l}\text { Protein } \\
(\mathrm{mg} / \mathrm{mL})\end{array}$ & $\begin{array}{l}\text { Specific activity } \\
(\mathbf{U} / \mathbf{m g})\end{array}$ & $\begin{array}{l}\text { Purification } \\
\text { factor }\end{array}$ \\
\hline Crude extract & 891.67 & 1.3 & 685.9 & 1.0 \\
\hline Precipitation & 1608.33 & 2.0 & 804.17 & 1.17 \\
\hline $\begin{array}{l}\text { Sephadex G- } \\
75\end{array}$ & 1078.00 & 0.95 & 1.134 & 1.65 \\
\hline
\end{tabular}

Table 2 Effect of detergents, organic acids, inhibitors, and metal ions on the activity of alkaline protease from $B$. firmus 


\begin{tabular}{|c|c|c|}
\hline Detergents, organic acids, inhibitors, or metallic ions & Concentration & Protease activity (\%) \\
\hline \multirow[t]{3}{*}{ SDS } & $0.5 \%(v / v)$ & 97.47 \\
\hline & $1 \%(v / v)$ & 107.37 \\
\hline & $5 \%(\mathrm{v} / \mathrm{v})$ & 121.89 \\
\hline \multirow[t]{3}{*}{ Triton $\mathrm{X}-100$} & $0.5 \%(\mathrm{v} / \mathrm{v})$ & 61.52 \\
\hline & $1 \%(v / v)$ & 59.68 \\
\hline & $5 \%(v / v)$ & 54.61 \\
\hline \multirow[t]{3}{*}{ Tween-20 } & $0.5 \%(v / v)$ & 66.36 \\
\hline & $1 \%(v / v)$ & 61.52 \\
\hline & $5 \%(v / v)$ & 57.14 \\
\hline \multirow[t]{3}{*}{ Butanol } & $0.5 \%(v / v)$ & 68.20 \\
\hline & $1 \%(v / v)$ & 65.44 \\
\hline & $5 \%(v / v)$ & 54.61 \\
\hline \multirow[t]{3}{*}{ Methanol } & $0.5 \%(v / v)$ & 72.35 \\
\hline & $1 \%(v / v)$ & 70.74 \\
\hline & $5 \%(v / v)$ & 67.28 \\
\hline \multirow[t]{3}{*}{ Isopropanol } & $0.5 \%(v / v)$ & 68.20 \\
\hline & $1 \%(\mathrm{v} / \mathrm{v})$ & 67.51 \\
\hline & $5 \%(v / v)$ & 62.44 \\
\hline \multirow[t]{3}{*}{ DMSO } & $0.5 \%(v / v)$ & 74.89 \\
\hline & $1 \%(v / v)$ & 61.06 \\
\hline & $5 \%(v / v)$ & 56.45 \\
\hline \multirow[t]{3}{*}{ EDTA } & $0.5 \%(v / v)$ & 68.20 \\
\hline & $1 \%(v / v)$ & 65.44 \\
\hline & $5 \%(v / v)$ & 54.61 \\
\hline \multirow[t]{3}{*}{$\beta$-mercaptoethanol } & $0.5 \%(v / v)$ & 72.35 \\
\hline & $1 \%(v / v)$ & 70.74 \\
\hline & $5 \%(v / v)$ & 67.28 \\
\hline \multirow[t]{2}{*}{$\mathrm{Cu}^{2+}\left(\mathrm{CuCl}_{2}\right)$} & $0.01 \mathrm{M}$ & 49.87 \\
\hline & $0.005 \mathrm{M}$ & 53.04 \\
\hline
\end{tabular}




\begin{tabular}{|lll|}
\hline $\mathrm{Ni}^{2+}\left(\mathrm{NiSO}_{4}\right)$ & $0.01 \mathrm{M}$ & 41.22 \\
\hline $\mathrm{Ca}^{2+}\left(\mathrm{CaCl}_{2}\right)$ & $0.005 \mathrm{M}$ & 43.11 \\
\hline $\mathrm{Fe}^{2+}\left(\mathrm{FeSO}_{4}\right)$ & $0.01 \mathrm{M}$ & 76.31 \\
& $0.005 \mathrm{M}$ & 88.46 \\
\hline $\mathrm{Cu}^{2+}\left(\mathrm{CuSO}_{4}\right)$ & $0.01 \mathrm{M}$ & 49.20 \\
& $0.005 \mathrm{M}$ & 51.02 \\
\hline $\mathrm{Mn}^{2+}\left(\mathrm{MnSO}_{4}\right)$ & $0.01 \mathrm{M}$ & 50.80 \\
& $0.005 \mathrm{M}$ & 53.76 \\
\hline $\mathrm{Mg}^{2+}\left(\mathrm{MgSO}_{4}\right)$ & $0.01 \mathrm{M}$ & 63.16 \\
& $0.005 \mathrm{M}$ & 72.12 \\
\hline $\mathrm{Zn}^{2+}\left(\mathrm{ZnSO}_{4}\right)$ & $0.01 \mathrm{M}$ & 66.64 \\
& $0.005 \mathrm{M}$ & 71.67 \\
\hline
\end{tabular}

\section{Figures}
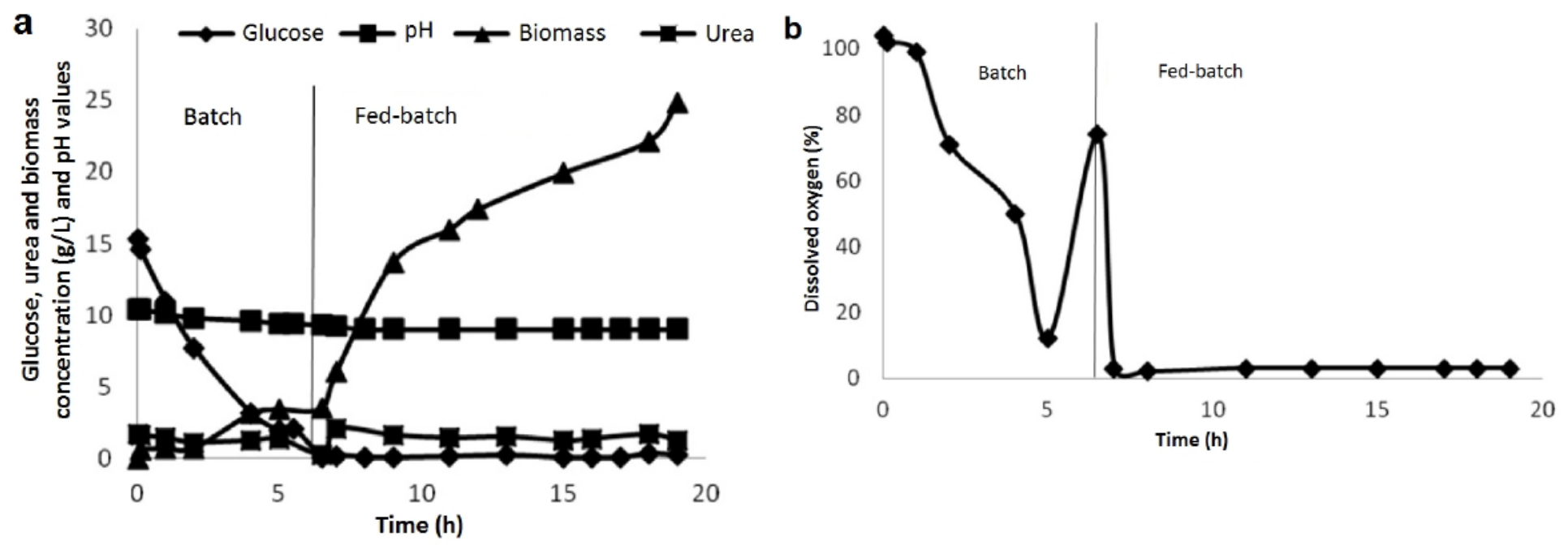

Figure 1

Kinetic fermentation in fed-batch for protease production by B. firmus. In the panel (a) is glucose, urea, and biomass concentration $(\mathrm{g} / \mathrm{L})$ and $\mathrm{pH}$ values during the fermentation process, and in the panel $(\mathrm{b})$ is the percentage of free oxygen in the fermentation broth through the process 


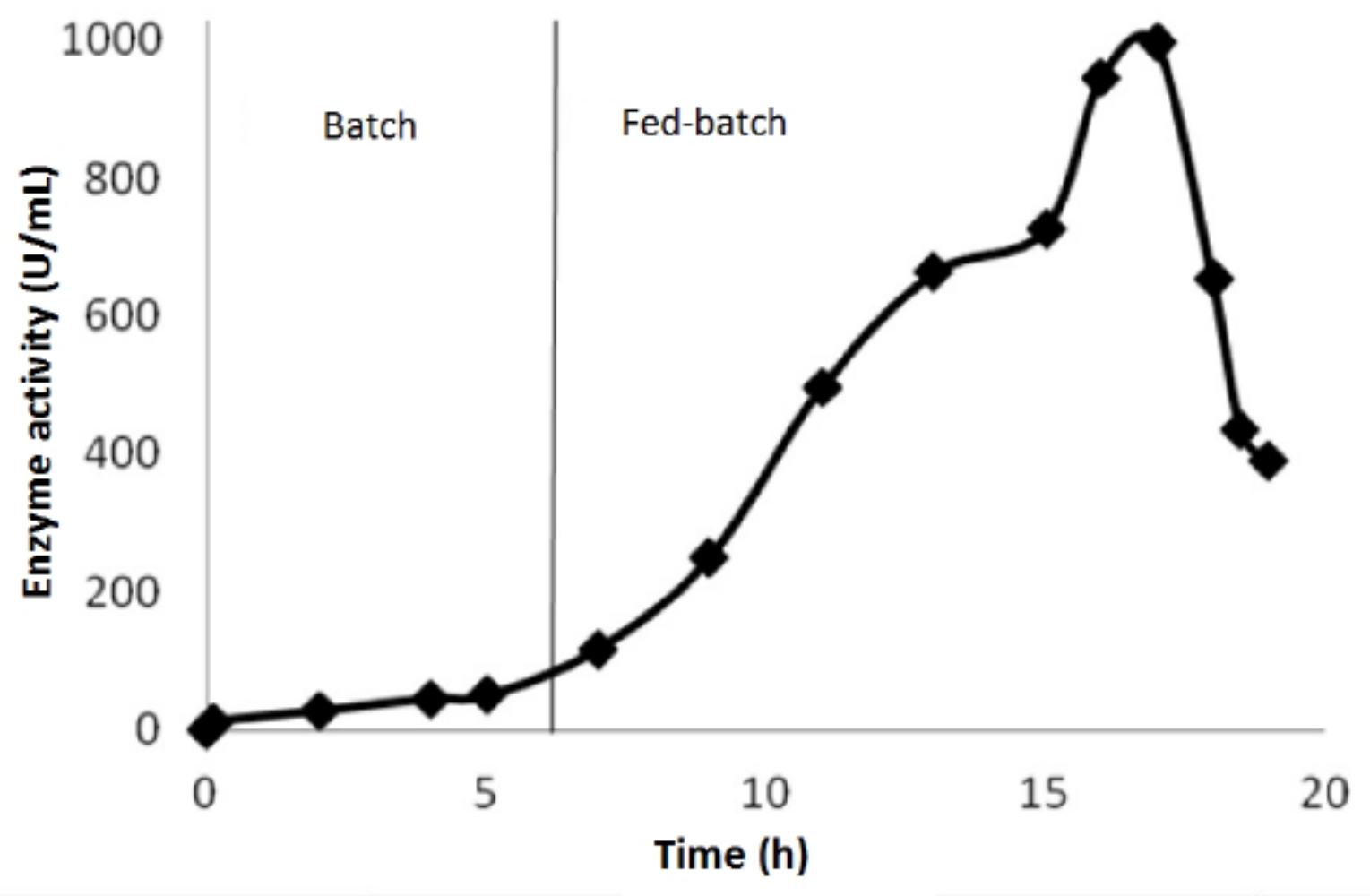

Figure 2

Curve enzymatic activity of the protease from B. firmus during the fermentation in batch and fed-batch

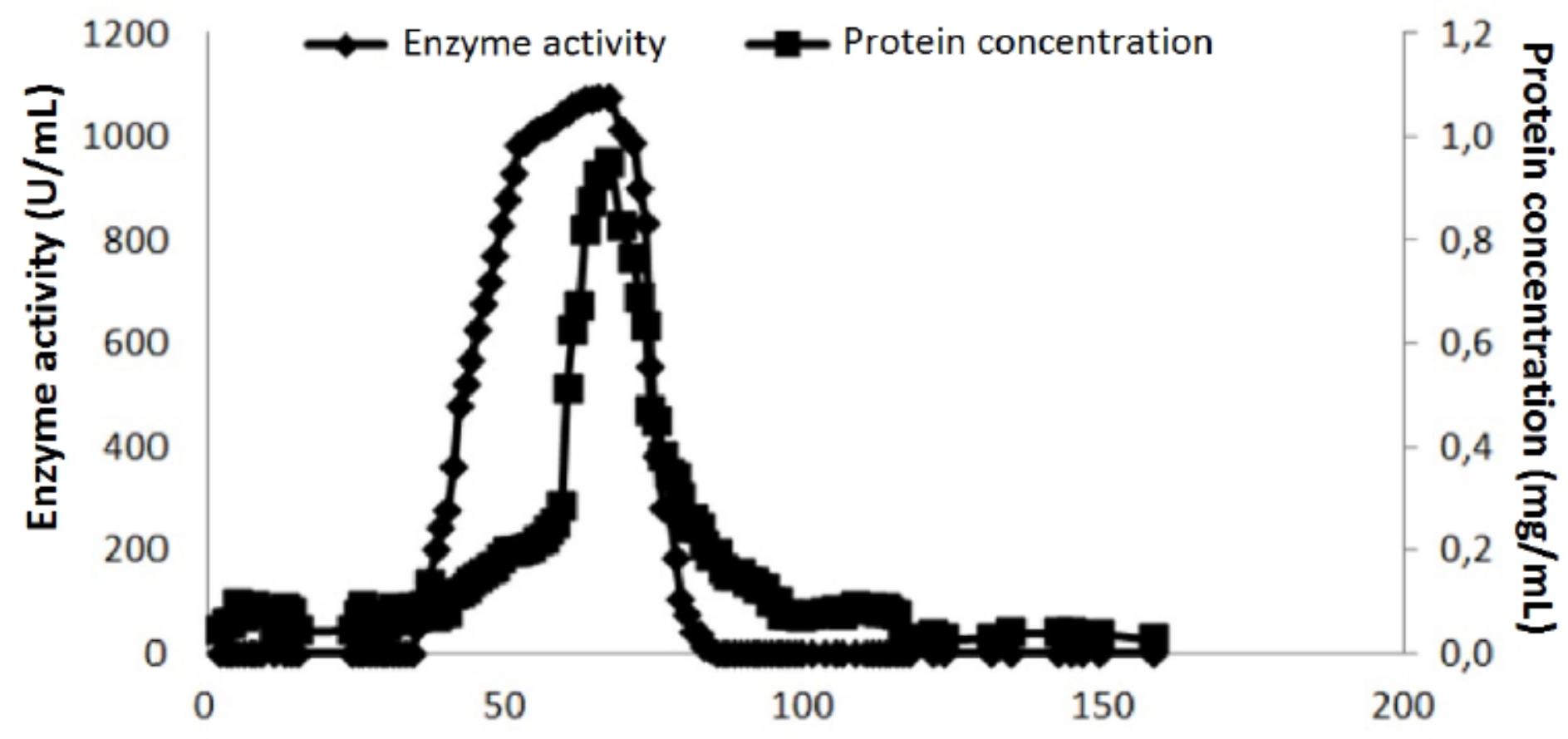

Figure 3 
Elution pattern of the alkaline protease from B. firmus on a gel-filtration liquid chromatography column (Sephadex G-75)
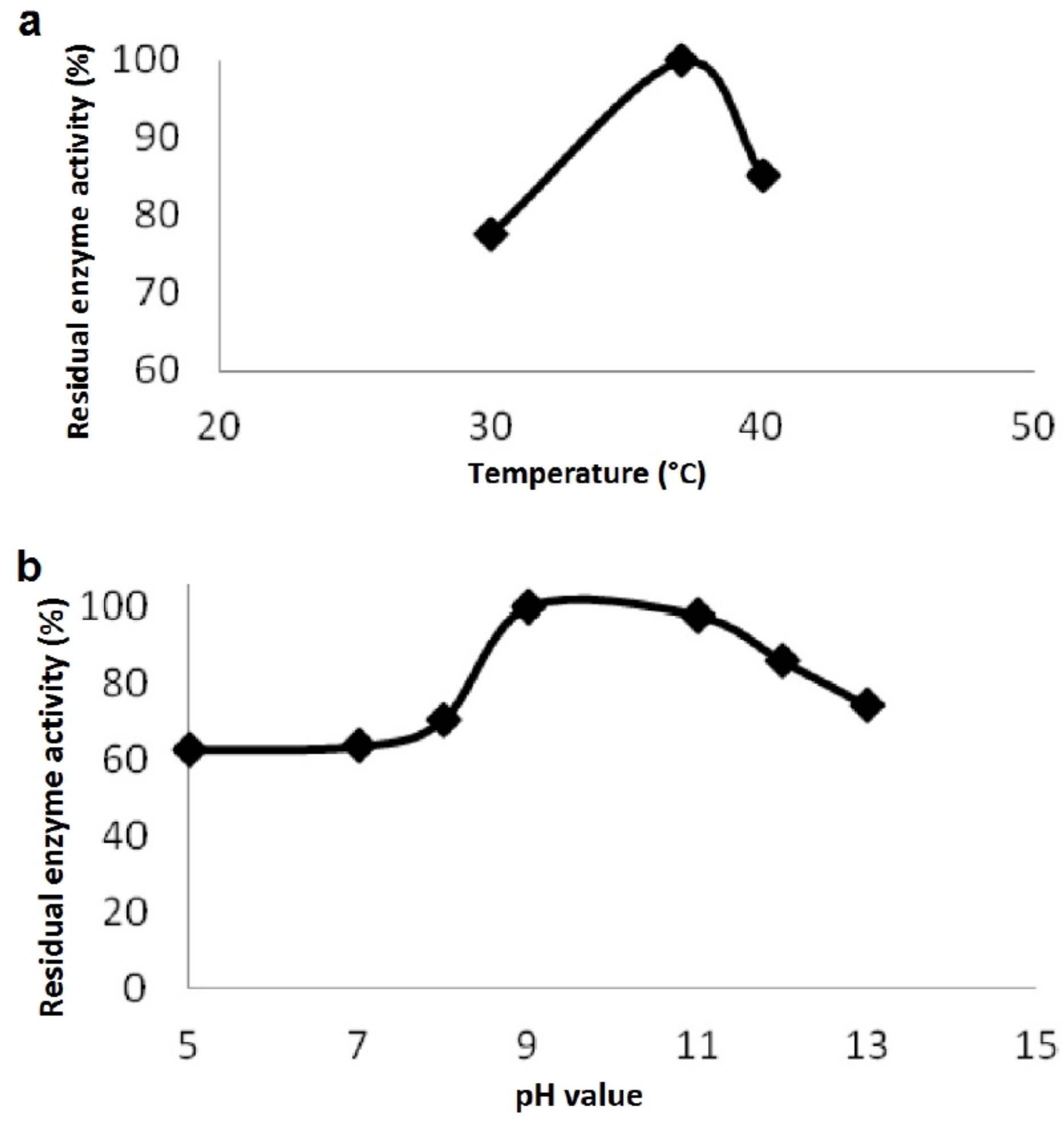

Figure 4

Enzymatic assay of the protease from B. firmus at different temperatures $\left(30,37\right.$, and $\left.40^{\circ} \mathrm{C}\right)$, in panel (a), and the effect of $\mathrm{pH}$ variation on the protease activity in panel (b) 

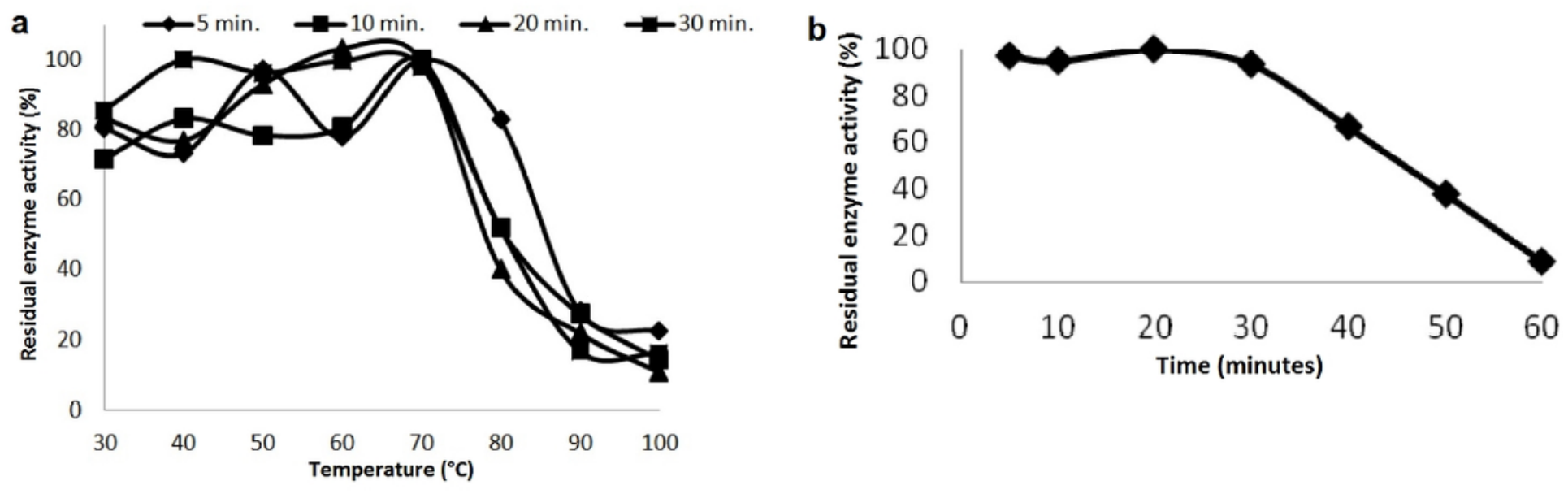

Figure 5

Effect of temperature at different incubation times on the enzyme activity of the protease from B. firmus, in panel (a), and protease thermal stability profile, in panel (b) 